\title{
ECULTURAL REPRESENTATION OF TORAJA ETHNIC ON THE USE OF VOCABULARY IN SINGGI' SPEECH
}

\author{
Anastasia Baan ${ }^{1)} \&$ Imam Suyitno ${ }^{2)}$ \\ Universitas Kristen Indonesia Toraja ${ }^{1)} \&$ Universitas Negeri Malang ${ }^{2}$ \\ email: anasbaan@ukitoraja.ac.id
}

\begin{abstract}
The Toraja ethnic has an oral tradition of Singgi' which is passed down orally from generation to generation. This tradition is carried out at rituals, which are spoken by tradition holders or groups of people. The study outlined in this article aimed to describe the Toraja ethnic culture represented in the vocabulary in Singgi' speech. The focus of this study was to describe the cultural dynamic and the cultural attitude of Toraja ethnic represented in vocabulary in Singgi' speech. The study was conducted through a qualitative approach using hermeneutic analysis tools. The data of this research were speech in Singgi 'and the daily context and activities of the people of Tana Toraja. The data was collected through document studies, interviews, and observations. Through qualitative analysis and hermeneutic interpretation, it was found that in Singgi' speech, there was an absorption of vocabulary from Indonesian and old vocabulary in Toraja. The diversity of vocabulary represented that in Tana Toraja society there was a cultural dynamic that requires the Toraja language to absorb vocabulary from other languages to convey the cultural messages. Singgi' speech used old words of Toraja language that were rarely used in daily communication to convey the cultural attitudes of the Tana Toraja people. The findings showed that the vocabulary used in Singgi' speech represented the Toraja ethnic culture. This finding has important benefits in preserving the culture of the Tana Toraja community, for teaching material in the development of character education, and as a reference in developing further studies.
\end{abstract}

Keywords: cultural representation, Toraja ethnic, vocabulary, Singgi'speech

\section{REPRESENTASI BUDAYA ETNIK TORAJA PADA PENGGUNAAN KOSAKATA DALA TUTURAN SINGGI'}

\begin{abstract}
Abstrak
Etnik Toraja memiliki tradisi lisan Singgi 'yang diturunkan secara lisan dari generasi ke generasi. Tradisi ini dilakukan pada ritual, yang dituturkan oleh pemegang tradisi atau kelompok orang. Hasil kajian yang diuraikan dalam artikel ini bertujuan untuk menggambarkan representasi budaya etnik Toraja dalam penggunaan kosakata dalam tuturan Singgi'. Kajian ini memfokuskan pada pemahaman dinamika budaya dan sikap budaya etnis Toraja yang terepresentasikan pada kosakata dalam tuturan Singgi'. Penelitian dilakukan melalui pendekatan kualitatif dengan menggunakan piranti analisis hermeneutik. Data penelitian ini berupa tuturan Singgi' dan konteks perilaku kesehrian masyarakat Tana Toraja. Data dikumpulkan melalui studi
\end{abstract}


dokumen, wawancara, dan observasi. Melalui analisis kualitatif dan interpretasi secara hermeneutik, ditemukan bahwa dalam tuturan Singgi', terdapat sejumlah kosakata serapan dari bahasa Indonesia dan kosakata lama dalam bahasa Toraja. Munculnya kosakata serapan tersebut merepresentasikan bahwa dalam masyarakat Tana Toraja ada dinamika budaya sehingga mengharuskan bahasa Toraja untuk menyerap kosakata dari bahasa lain untuk menyampaikan pesan budaya. Dalam menyampaikan sikap budayanya, etnik Toraja menggunakan kosakata lama yang tidak pernah digunakan lagi dalam komunikasi keseharian masyarakat Tana Toraja. Temuan ini memiliki manfaat penting dalam melestarikan budaya masyarakat Tana Toraja, untuk bahan ajar dalam pengembangan pendidikan karakter, dan sebagai referensi dalam mengembangkan studi lebih lanjut.

Kata kunci: representasi budaya, etnik Toraja, kosakata, tuturan Singgi'

\section{INTRODUCTION}

Toraja ethnic is one of the ethnic groups living in the Tana Toraja region. The term ethnic Toraja is recognized based on their place of residence, namely ethnic groups living in the highlands (Nooy-Palm, 1975). In the highlands, several languages can be said to be dialects, social strata, and practices of ritual tradition. In carrying out their daily activities, the Toraja people in general have business relations with the Bugis, Makasar, and Mandar tribes. They rarely carry out trade interactions internally with fellow tribes in the highlands. The Tana Toraja people are aware of the unity of their ethnic social identity when Dutch missionaries are present in the region (Adam, 1990). The awareness of the Toraja ethnicity increased the number of ethnic groups in South Sulawesi to four ethnic groups, namely the Bugis, the Makassarese, the Mandarese, and the Toraja (Adams, 1995).

The Toraja ethnic has an oral tradition of Singgi' which is passed down orally from generation to generation. This tradition is carried out at rituals, which are spoken by tradition holders or groups of people. As an oral tradition, the Singgi' also includes Toraja oral-literary treasures that use language as a vehicle for delivering messages through his speech. As a vehicle for delivering the message, the speech in the Singgi' contains cultural values that are alive and embraced by the Tana Toraja community as the owner of Singgi' (Pamungkas, 2012). In line with this statement, it can be argued that Singgi' is a cultural product as well as a cultural vehicle for Tana Toraja people in establishing communication among their ethnic groups (Ibrahim et al., 2006). By utilizing speech in Singgi', the Tana Toraja community communicates and develop their culture in social life.

As stated in the description above, Singgi' is a cultural product as well as a cultural medium for the Tana Toraja community which is passed on orally. As an oral tradition, Singgi' has several characteristics, namely (1) in the form of oral literature, (2) traditional technology, (3) containing religious and belief elements, (4) artistic form, and (5) being a role model (Hutomo, 1991). 
Oral tradition is an ancestral heritage that contains and uses metaphorical words to convey cultural meanings and messages. Singgi' oral tradition 'is a cultural wealth that directs and guides members of the Tana Toraja community to understand the culture of the ancestors through cultural practices that have been traded for centuries (Sikki, 1986).

Oral tradition is often equated with folklore because all folklore criteria meet the oral tradition criteria. However, some people consider that oral tradition is more accommodating of aspirations, while folklore is often connoted as a matter of doubtful truth (Hutomo, 1991). Folklore is a collective tradition (Danandjaja, 1984). Folklore is a part of a culture that is traditional, informal, and non-institutional (Pusposari, 2011).

As an oral tradition, the vocabulary used in Singgi' speech reflects the culture of the Tana Toraja community as its owner. The vocabulary used in Singgi' speech role as a cultural code that reflects the culture of the owner's community. This is in line with the statement of Fought (2006) which explained that each community has its way of interpreting their world, which is then coded in language. Furthermore, Sapir (in Wardhaugh, 2009) asserted that the cultural diversity of society is encoded and reflected in its language. Based on this statement, it can be revealed that the vocabulary used in the Singgi' speech is a recording and reflection of the culture of the people of the Tana Toraja region as its speakers.

Community culture in the area of Tana Toraja is a cultural heritage of the old generation that has experienced development due to the influence of the culture of other regional communities. The development of Toraja ethnic culture is due to interactions with other ethnic groups outside the Toraja and the entry of other ethnic groups into transmigrants in the region. The culture of the Tana Toraja community is integral as well as a universal cultural unit, namely the Indonesian national culture. Therefore, whether we realize it or not, the Toraja culture receives a large national influence in its development. Other cultural influences that enter the culture of the Tana Toraja community can be seen in the use of a variety of languages, especially in the use of vocabulary contained in cultural products, among them are Singgi.

The above description illustrates that the relationship between language and the speaker community is very close and influences each other. The development of language occurs due to the development of the communication process which is a demand for social needs that occur among these communities. And vice versa, changes in people's behavior in their daily lives, changes in the status and position of community members, and changes in the role of community members in social structures influenced by the development of the language. The development of the language is a cultural development or change that has broad implications for changes in addressing life and perceiving developments and conditions that develop in their environment (Jones, 2015).

Changes in the cultural perception of the Tana Toraja community towards their living environment, both ecological and socio-cultural environments, 
require changes in communication systems and facilities that encourage the emergence of new vocabulary as an effort to fulfill these communication needs (Sugiarti \& Putra, 2019). The emergence of new words or absorption words in the language used by the Tana Toraja community is evidence of communication demands that require language vehicles to convey cultural messages in their social interactions. This fact is proof that the Toraja language always develops along with the cultural development of the Tana Toraja community.

Starting from the description above, this study seeks to describe the representation of Toraja ethnic culture in the vocabulary used in Singgi' speech. By these objectives, the focus of this study was limited to the description of (a) the cultural dynamic of the Toraja ethnic represented in Singgi' speech vocabulary and (b) cultural attitude of the Toraja ethnic represented in Singgi' speech vocabulary. The findings of this study have a significant contribution to developing insight and understanding of the cultural messages of the Tana Toraja community. Besides, the results of this study can be a useful document in maintaining Tana Toraja culture.

\section{METHOD}

This research was cultural studies conducted by using a qualitative approach with a hermeneutic as an analysis tool. Research data in the form of speech in Singgi' which developed in the life of the Tana Toraja community. To interpret the Toraja ethnic culture in Singgi' speech, this study also collected data in the form of the context and daily activities of the Tana Toraja community. To collect this data, researchers conducted document studies, interviews, and observations. As a key instrument, researchers used data collection aids in the form of observation guides, interview guides, and recording devices (camcorders).

Data analysis was carried out qualitatively by hermeneutic interpretation of findings. Hermeneutics functions as an interpretation system (Wehmeyer \& Palmer, 2003). Qualitatively, data analysis is carried out through the stages of data selection, data reduction, data classification and categorization, interpretation and explanation of data, and concluding. Interpretation of research data uses a model that follows Ricoeur's view. An interpretation is needed because of the plurality of meanings. The purpose of hermeneutics is to eliminate a mystery contained in a symbol. Each interpretation is an attempt to find meanings that are still veiled in the meaning of literature. Ricoeur (in Sumaryono, 1999) explains that an understanding process can be carried out through three steps, namely (1) symbolic understanding, namely efforts to recognize and understand symbols and relationships between symbols, (2) the meaning and excavation of symbolic meaning carefully, and (3) ) use of symbols to find cultural significance. These three steps are closely related to the three stages of language understanding, namely: (1) the semantic stage, (2) the reflection phase, and (3) the existential stage (Ricoeur, 2002). 


\section{FINDINGS AND DISCUSSION}

\section{Finding}

In accordance with the focus that was studied, the results of the study included two aspects, namely (a) the dynamics of the Toraja ethnic culture represented by the use of vocabulary, and (b) the attitude of the Toraja ethnic culture represented through the use of vocabulary in Singgi speech. Both aspects are presented in Table 1 .

Tabel 1. Toraja ethnic culture dynamic and attitude which represented in vocabularies of Singgi' Speech

\begin{tabular}{cll}
\hline No. & \multicolumn{1}{c}{ Aspect } & \multicolumn{1}{c}{ Description } \\
\hline 1. & $\begin{array}{l}\text { The Cultural Dynamic of Toraja Ethnic } \\
\text { which represented in vocabularies of } \\
\text { Singgi' speech }\end{array}$ & $\begin{array}{l}\text { a. Vocabulary in Singgi' Speech which adopted from } \\
\text { Indonesian } \\
\text { b. Vocabulary in Singgi' Speech which adapted from } \\
\text { Indonesian } \\
\text { c. Vocabulary in Singgi' Speech which Revealed } \\
\text { from old vocabulary of Toraja Language }\end{array}$ \\
& $\begin{array}{l}\text { The Cultural Attitude of Toraja Ethnic } \\
\text { which represented in vocabularies of } \\
\text { Singgi' speech }\end{array}$ & $\begin{array}{l}\text { Personality Attitudes } \\
\text { b. Old vocabulary in Singgi' Speech for Expressing } \\
\text { the Attitude in Social Interaction }\end{array}$ \\
\hline
\end{tabular}

\section{Discussion}

\section{Toraja Ethnic Culture Dynamic which} Represented in Vocabularies of Singgi' Speech

Singgi' was spoken by tradition holder of Toraja ethnic in the Toraja language. In the speech of Singgi', there were several absorption words and old words of Toraja Language. The vocabularies used in the Singgi' speech can be exemplified in the following quotation.

\section{Vocabulary in Singgi' Speech which adopted from Indonesian \\ Vocabulary in Singgi' speech which adopted from Indonesian can be exemplified in the following quotation.}

\section{Quotation 1}

Bendan tau-tau nangka/Sola

tobombo dikita/Lolongmi rante

kalua'/ Tama tandung kalonaran
[Standing jackfruit wood statue/

Picture of a spirit in sight/Flowing man in a large courtyard/Entering the yard of mourning]

\section{Quotation 2}

Inde anak mamasena/Sola ampo

kaboro'na/Sumullukmo tama

rampanan kappa/Tidukun lan

pa'sullean allo [This is a beloved child/And dear grandson/Has entered into a marriage/Entered into a marriage]

\section{Quotation 3}

Inde allo totemo/Kulla' tarande lulangan/Siampa' sampena bulan/ Sumbung sulona pa'taunan [On this day/Light rises to the top/ Simultaneously the appearance of the moon/Rising Sun.]

In quotation 1-3, there are the words nangka 'jackfruit', anak 'child', and bulan 'moon'. The vocabularies 
were Indonesian vocabulary absorbed directly without changing its sound and meaning. The meaning of the word nangka in the speech is the same as the meaning of the word nangka in Indonesian, which refers to 'a kind of tree'. The meaning of the word anak in Singgi; speech is the same as the meaning of the word anak in Indonesian, which refers to 'mentioning the person he considers a child'. Likewise, the meaning of the word bulan in the speech refers to the same meaning in Indonesian, i.e 'celestial body which is a satellite of the earth that appears at night'.

\section{Vocabulary in Singgi' Speech which adapted from Indonesian \\ Vocabulary in Singgi' speech which} adapted from Indonesian can be exemplified in the following quotation.

\section{Quotation 4}

Nakua pa'kadananna/Sumbung pudukna kumua/La lao langnganmo' langi'/La dao to palullungan [Then he said/Replied in his mouth/I will ascend to langit 'sky/heaven' / Will be above heaven]

\section{Quotation 5}

Ia tonna didadian/Randukna ditibussanan/Silalle-lallemi guntu'/

Sileleanna galugu [When born/ Starting out of the womb/Guntur 'Thunder' shout/Followed by a roar]

In quotations 4-5, there are the words langi and guntu which are absorption words adapted from the Indonesian vocabulary. Writing the word langit in the Singgi', the letter [t] in the word langit is replaced by a sign ['] so that the pronunciation becomes [langi']. The meaning of the word langi in the speech refers to the same meaning as the word langit in Indonesian, which is 'the vast space that extends on the face of the earth, where the moon, the sun, the stars' reside. For the people of Tana Toraja, langi' is analogous to the location of heaven that is above the sky. Writing the word guntur in Singgi', the letter $[\mathrm{r}]$ in the word 'guntur' is replaced by a sign ['] so that the pronunciation becomes [guntu']. The meaning of the vocabulary of guntu 'refers to the same meaning as the vocabulary of guntur in Indonesian, which is 'sound that blasts in the air'. The vocabulary of thunder for the people of Tana Toraja signifies 'rain will fall'.

\section{Vocabulary in Singgi' Speech which Revealed from Old Vocabulary of Toraja Language}

The use of the old Toraja vocabulary in Singgi' speech can be exemplified in the following quotation.

\section{Quotation 6}

To laen-laen dadinna/Senga' kombong garaganna/To dadi dao pussana/ Ombo' dao tallobona [The other person was born/who was different from him/who was made in the sky/born on the clouds]

\section{Quotation 7}

Umbangun lando longa/Unnossok sale a'riri/Tonna randuk didadian/ Tonna kombong mentolino [He built a long roof house/Founded a pole building/When he was born/ When he became a human] In quotation 6 , there is the word ombo that is never used in daily communication. The word ombo in everyday communication of the Toraja regional language is replaced by didadian which means 'born'. For the people of the Tana Toraja region, said 
ombo, in the context of the Singgi', it indicates that the deceased person has been reborn like a newborn baby on this earth. So in the view of the ethnic Toraja, the deceased person has been reborn into eternal life in heaven.

In quote 7 , the word mentolino kombong in the Tana Toraja regional language means dadi tau which means 'to be human'. For the people of the Tana Toraja region, the word mentolino kombong is a vocabulary that tells that when humans were created by God on earth through a birth process, at that time humans were already grasping their respective fortune given by God, the human task is how to live life as well as possible. the good.

Based on the description above, it can be revealed that the vocabulary used in Singgi' speech, in addition to the everyday Toraja vocabulary, also absorbs vocabulary from Indonesian and old vocabulary in Toraja. The diversity of vocabulary in Singgi', on the one hand, shows that the Toraja language always develops according to the communication needs of the Tana Toraja community. On the other hand, the presence of absorption words in the speech can be said as an indicator that the Toraja language can not meet and reach the communication needs of the Tana Toraja community to convey cultural messages in social interaction.

The obsorption of several words in Singgi' speech indicates that in Toraja language, there is no word to contain the intended concept. Meanwhile, the concept has an important significance in the culture of the Tana Toraja community. For the people of Tana Toraja, the "jackfruit tree" is a very strong and durable tree. Thus, the people of the Tana Toraja region utilize the jackfruit tree to be used as a basic material in making sculptures. Jackfruit wood sculpture is a tradition of the people of the Tana Toraja region. If there is a dead person who will carry out his traditional funeral, the dead person will immediately be made a statue made of jackfruit wood and carved to resemble the face of the dead person. The use of jackfruit vocabulary in Singgi' is a metaphorical expression that expresses the robustness and immortality of the deceased person.

The absorption of the word nangka in Singgi indicates that the people of Tana Toraja have knowledge about flora but in the Toraja language, the vocabulary to contain the concept is not found. The knowledge about flora has economic functions, social cultural functions, and environmental functions (Sumaatmadja, 2003). From an economic point of view, plants function as meeting the needs of food, clothing, and shelter. Tana Toraja people's knowledge about flora (plants) can be known through the experience of the community itself, especially in managing the environment. The Tana Toraja community has some knowledge about plants. This can be seen from the vocabulary expressed in Singgi'.

In the culture of the Tana Toraja community, the mention of a child is not only aimed at people who have blood relations but can also be used for mentioning for younger people. It expresses the feelings of unfortunately older people to younger people. That feeling is awakened by the existence of one's interactions with others. The use of the word in their interaction produces a perception of a person concerned 
(Suryani, 2013). Porter and Samovar (in Mulyana \& Rakhmat, 2009) explained that perception is an internal process carried out by someone to choose, evaluate, and organize stimuli from the external environment. Perception is essentially an attempt to change one's physical environment into a meaningful experience.

For the people of Tana Toraja, the bulan 'moon' marks a good time to carry out various activities. In other words, the moon is a guide for the people of the Tana Toraja area to carry out various activities, for example, planting rice, carrying out marriages, and so on. The vocabulary belongs to the category of the cosmos, namely the vocabulary that refers to cosmic objects. These cosmos objects have characteristics in nature, can be sensed, and occupy a space. Included in the above-mentioned cosmos objects are the sun and moon.

The use of 'sky' and 'thunder' vocabulary in Singgi' reflects the interaction between the Tana Toraja people and the two cosmos objects. Their perception of cosmic objects is inseparable from their long experience in interacting with these objects and the cultural traditions that apply and develop in their area. This is what later developed into the Tana Toraja people's trust in the cosmos. Natural events that are believed to have negative values need to be avoided and sought so that these events do not occur, while those believed to be positive need to be maintained. To make avoidance so that they still get good luck in their lives. The people's trust in the Tna Toraja community is a legacy from the ancestors. This trust is passed down through speech media which are explained by signs or causes and which are expected to have consequences (Danandjaja, 1984).

Based on the description above, if it is integrated with the views of Wortham \& Perrino (2017), the Toraja language can be said as a vehicle or media used by community members to fulfill their daily needs. The emergence of absorption words in Singgi' speech indicates that the Toraja language has not been able to be as a whole as a mediation system that characterizes the communication of the Tana Toraja community to convey messages in certain matters. In line with $\mathrm{Hd}$ \& Muttaqin (2018), it can be said thet the Tana Toraja community has broader cultural knowledge and experience than the amount of mental content their language vocabulary can reach. That knowledge and experience come from outside its ethnic culture so that it has not been recorded in the language vocabulary.

In the quotation above, it can be observed that the vocabulary used in Singgi' speech varies. At each stanza Singgi', thereisold vocabularyspecifically used in the verse and cannot be replaced by another vocabulary because it will change the meaning of the message being conveyed. The vocabulary is metaphorical words that have special meanings to convey cultural messages. This is in line with the findings of the study of Tanduk (2012) which revealed that the majesty used at singgi is a symbolic form used to express a specific purpose. Among them are symbolic, fable, paralleling, hyperbole, preterite, pleonasm, synesthesia, precertification, antithesis, and metenomia, post-toto, allegory, and euphemism. By using this form, speakers Singgi 'can describe the level of stratification of the community 
by using language styles so that they have high aesthetic value.

Based on the discussion above, it can be said that Singgi' in the Tana Toraja community is used as a medium of community expression to communicate his life experiences and certain interests to others in the Tana Toraja community. Tanduk(2016) describes Singgi' function to (a) describe family relationships with people who come to the place of the deceased. (b) describe the position of a person, such as to Makaka, the rich, descendants of the Puang, ma'dika, Parengge', (c) describe a person's courage in defending his territory, and (d) explain the symbol of the family's traditional house, in terms of customs and ancestors of Tongkonan. Herianah (2016) \& Sudarsi et al. (2019) says that Singgi' in the form of a hymn is a form of prayer and gratitude that is spoken in a Toraja ceremony or tradition that contains the values of Toraja local wisdom. Meanwhile, Sandarupa (2015) defines singgi 'as praise for Tomina or the priest of Aluk To Dolo.

\section{The Cultural Attitude of Toraja Ethnic which Represented in Vocabularies of Singgi'Speech}

The old vocabulary of the Tana Toraja regional language is the original vocabulary of the Toraja language that is never used in daily communication. The vocabulary is only used in Singgi' to convey messages that have a specific meaning. The old vocabulary is usually used in every activity or traditional ceremony in the Tana Toraja region, for example at thanksgiving ceremonies or what are called tuka signs and funeral rites or what are called rambu solo. The vocabulary contains messages, advice, or good values that need to be obeyed by the people of the Tana Toraja region.

The old vocabulary of the Toraja language in Singgi 'which reflects the attitude of the Toraja ethnic culture can be classified in 3 categories, namely (a) the old vocabulary for expressing the attitude of personality, (b) the old vocabulary for expressing the attitude in the social interaction of the community, and (c) the old vocabulary for expressing the attitude of belief. The three types of vocabulary can be observed in the following quotation.

\section{Old Vocabulary in Singgi' Speech Reflecting Personality Attitudes}

In Singgi' speech, the old vocabulary of the Toraja language reflecting the attitude of personality can be exemplified in the following quotation.

\section{Quotation 8}

Suru'na tengko tiranduk/Sola ayoka panoto/Ma'doke-doke rangka'na/ Ma'pasoan tarunona/Sitondon tindo bonginna/Sola mamma'karoenna [Worship to cultivate the land/ Ceremony to plant the plow/His fingers like a spear/His fingers as sharp as high/Be under dreams/ Together with his sleep]

In quotation 8 , there is the word tengko tiranduk which in the Tana Toraja regional language means ma'jama which means 'cultivating the land'. For the people of the Tana Toraja region, the tengko tiranduk vocabulary signifies someone diligent in working in the fields or in the garden to fulfill his daily needs.

\section{Quotation 9}

Lobo'mi tallu bulinna/Sumarre tallu etengna/Kendek patuku ma'dandan/ Sola po'ko sielongan [Fertilize the 
rice plants / Fertile like cereals / The higher the stacking / Pile of rice harvest]

In quotation 9, the word tallu bulinna is used which in the regional language Tana Toraja means pare which means 'rice'. Furthermore, word tallu etengna in the regional language Tana Toraja means sarre which means 'lemongrass'. For the people of the Tana Toraja area the word tallu bulinna indicates a smart but humble person such as rice which increasingly contains more and more conundrums. Furthermore, the vocabulary of tallu etengna for the people of the Tana Toraja region indicates the condition of the people of the Tana Toraja area who live in harmony.

\section{Quotation 10}

Bala tedong marapuan/Bontong ma'lako-lakoan/Kayunna membua ringgi'/Sola menta'bi eanan [The buffalo is getting more and more / The cages are scattered everywhere / The trees produce money / The property is rich]

In quotation 10 , there is a word membua ringgi' which in the regional language of Tana Toraja means mendadi seng which means 'being money'. Furthermore, the word menta'bi eanan in the regional language Tana Toraja means kasugiran which means 'wealth'. For the people of the Tana Toraja region, vocabulary makes a sign of someone who has a lot of money. Furthermore, the word menta'bi eanan for the people of the Tana Toraja region signifies someone who has a lot of property.

From the description above, it can be revealed that the old vocabulary of the Toraja language used in Singgi' illustrates the cultural attitudes of the speaker community. Harris and Moran (in Mulyana \& Rakhmat, 2009) explained that in life in society, directly recognizable community characteristics are differences that are related to communication systems and language systems. In the communication system and language system, several values and norms control and regulate the sociocultural activities of a society. These cultural values and norms serve as guidelines and guidelines for life which are upheld and obeyed by all members of the community. These cultural values are abstract and contain ideas that are considered good, true, and desired together by community members. In this case, Conklin (1984) stated that cultural values and norms regulate and direct the way people think, behave, and speak in certain situations.

In daily life, the Toraja people develop ethical attitudes in personality. In social life, they need to develop themselves as individuals. Green et al. (2019) explained that personality is the overall behavior of a person which is an interaction between innate tendencies with various series of situations surrounding his life. Personality is an attitude, prevalence, and thoughts that are owned by a person and is related to his role and position in various groups that affect his awareness (Shen et al., 2018). Concerning this personal life, Tana Toraja people have a variety of attitudes. Some personality attitudes expressed in Singgi' speech are (a) perseverance in trying, (b) activeness and creativity in work, and (c) politeness in acting. 
Old vocabulary in Singgi' Speech for Expressing the Attitude in Social Interaction

In Singgi'speech, the old vocabularies of Toraja language which express attitudes in social interaction can be exemplified in the following quotation.

\section{Quotation 11}

Umbangun lando longa/Unnossok

sale a'riri/Tonna randuk didadian/

Tonna kombong mentolino [He built

a long roof house / Founded a

pole building / When he was born

/ When he became a human]

In quotation 11 , there is a word mentolino kombong which in the daily communication of the Tana Toraja community is used the word dadi tau which means 'to be human'. For the people of the Tana Toraja region, the word mentolino kombong is a word telling that when humans were created by God on earth through a birth process, at that time humans were already grasping their respective fortune given by God, the human task is how to live life as well as possible. the good.

\section{Quotation 12}

Dadi taruk bulawanna/Tololosu

kandaurena/Natole tumangke suru'/

Tumentang passara'kasan [Born / his beloved child / His granddaughter lover / Again he worshiped /

Worshiped]

In quotation 12 , there is a word taruk bulawanna which in the Tana Toraja regional language for daily communication is used the word pia kaboro which means 'beloved child'. For the people of the Tana Toraja region, the vocabulary of the taruk bulawanna indicates that the child is the noblest treasure compared to other assets given by God in one family. Thus the birth of every child in a family, must be grateful.

\section{Quotation 13}

Den upa napoupa'/Paraya

napoparaya / Anna lambi'i matua

induk/Na dete'i bannu' karurungan

[Good luck / Good luck / Like

palm / Until old age]

In quotation 13, it is used the word matua induk which in the daily language of Toraja used matessek which means 'old'. For the people of the Tana Toraja region, the word matua induk signifies the integrity of husband and wife in a household to old age.

\section{Quotation 14}

Inde tongkonan layukna/Anna te lando longana/Mangkamo nabangun tang sala bangun/Nakombong tang sala suka [This is the center of the traditional house / The tallest one / It has been well established /

Properly made]

In quote 14 , there is a word tongkonan layuk which in the regional language of Tana Toraja for daily communication is used the word banua nene which means 'the center of a traditional house'. For the people of the Tana Toraja area, the word tongkonan layuk is the center of various traditional houses in one village to make or discuss customary regulations that apply in that village.

\section{Quotation 15}

Ma'bau pangden bambanal

Buandelen sulunanna/Padang ma'lite bumbungan/Ma'rara sendana bonga

[Good smells the door / Lots of

keys / The roof is gummy wood /

Big banyans are bleeding]

In quotation 15 , there is a word sendana bonga which in the regional language of Tana Toraja is used every day by the word parengge which means 
'a leader'. For the people of the Tana Toraja region, sendana bonga signifies the nature of a leader who protects his people.

\section{Quotation 16}

Lako kita sola nasang/Mintu'ki' ma'dio rengan/Lako inde to merrapu

tallang/Sola tomengkaponan ao'

[To us all / All present / To all

/ relatives / As well as all its

contents]

In quotation 16, there is a word merrapu tallang which in the Tana Toraja regional language for daily communication is used the word misa keluarga which means 'one family'. For the people of the Tana Toraja region, the word merrapu tallang signifies a family that lives in harmony and supports one another so that it is not easy to shake if there is a problem.

\section{Quotation 17}

Litak meriri litakna/Kalimbaun tida masak/Dipabendanni banual Diossokki lando longa [The land is yellow / the land is hard / A house is built / A long-roofed house is made]

In quotation 17, there is a word lando longa. The word in the Tana Toraja regional language for daily communication is replaced with the word banua kalando which means 'house with a long roof'. For the people of the Tana Toraja region, the word lando longa signifies a long curved roof that resembles the shape of a boat. The house is a traditional house of the Tana Toraja area called Tongkonan. The shape of the roof of the houses of the people of Tana Toraja region that resembles a boat was motivated by a long time ago the first rulers in the Tana Toraja area from the south of Tana
Toraja by using a boat called lembang as a means of transportation. These rulers passed the largest river channel in the Tana Toraja area, the Sa'dang River.

The data presented in the above quotation illustrates that the Toraja ethnic attitude in life in society is based and directed by their view of life. The view of life is the values adopted by the community that is chosen selectively by individuals and groupsinsociety(Udiati, 2016). This view of life functions as a code of conduct that regulates, controls, and gives direction to human behavior and actions in society.

In carrying out life activities in the community, the Toraja ethnic always need others as their social partners. They need help from each other to lighten the burden of life faced and cannot cope alone. Koentjaraningrat (2005) explained that the nature of human relations with humans/their neighbors is one of the basic problems in human life. In life in society, humans as individuals are only a small element that is surrounded by the community, society, and the natural surroundings. They depend on each other in their lives. Therefore, they must maintain good relations with each other.

In social life, Tana Toraja people try to build good relationships with fellow community members. They have the principle of social life that human relations in that society must be good. This good relationship can be built in various ways following the noble values that serve as his outlook on life. This good relationship is not only with his family or siblings, but also with neighbors, friends, and other people he does not know yet. 
In one social unit in the Tana Toraja community, several communities have their own needs and interests. The needs and interests of a community are different from the needs and interests of other communities (Mooney, 2011). The needs and interests of each community have led to the emergence of various cultural subsystems within that society. Each community, according to Porter and Samovar (in Mulyana \& Rakhmat, 2009), has a cultural subsystem that is different from other community cultural subsystems in a cultural system of society that surrounds it. This difference, according to Peccei (in Thomas et al., 2004), is caused by their differences in viewing the world around them.

As a social being, the Tana Toraja community has a responsibility to understand one another. Their freedom is limited by the freedom of others. They are bound by the values, norms, laws, and rules that apply and underlie their lives in society. According to Sumaatmadja (2003), they are also required to have a soul of "pride" which includes elements of courage, honesty, discipline, and responsibility. Without that attitude, they will live in seclusion in their lives in the community so that it is difficult to develop their potential.

The Tana Toraja People's closeness to nature shows their interaction with the surrounding environment. The relationship is not only a relationship of interdependence but manifested in a relationship that affects each other (Daeng, 2000). The community can not only utilize nature but can also change and process their environment to provide more benefits. With its culture, people can create certain forms of the environment by their creativity and adaptability in facing environmental challenges. Various perceptions and views and behavior of these people can only be known through functional relationships that are related so that they can maintain the sustainability of the ecosystem in their environment.

\section{Old Vocabularies in Singgi' Speech for Expressing the Attitude of Belief}

In Singgi' speech, the old vocabulary of the Toraja language expressing godliness can be exemplified in the following quotation.

\section{Quotation 18}

Nanai longke ma'bua/Tamayang ma'balinono/Randuk masaki ulunna/ Tikuramban beluakka [The place he performed the traditional ceremony / The great one / When he started to get sick / His hair was a mess] In quotation 18, there is a word ma'bua which is used in the daily communication of the Tana Toraja regional language umpogau sara' which means' conducting a traditional ceremony'. For the people of the Tana Toraja region, ma'bua is worshiping God through traditional ceremonies such as funeral rites.

\section{Quotation 19}

To laen-laen dadinna/Senga' kombong garaganna/To dadi dao pussana/

Ombo' dao tallobona [The other person was born / who was different from him / who was made in the sky / born on the clouds]

In quotation 19, there is an old Toraja vocabulary, which is ombo'. In Tana Toraja regionallanguage harmony, using the word didadian which means 'born'. For the people of the Tana Toraja 
region, the word ombo indicates that the deceased person has been reborn like a newborn baby on this earth, so the person who dies means being reborn into eternal life in heaven.

\section{Quotation 20}

Anna kasalle dadinna/Anna lolo garaganna/Naria tangkean suru/ To mai passara'kasan [Grow big /

Become more fertile / Nurtured thanks to family prayers / People who give thanks]

In quotation 20, there is a word tangkuban suru in the language of the Tana Toraja region for communication in the community the word passambanyanganna siunu' which means 'prayer from family or relatives'. Furthermore, the word passara' kasan in the Tana Toraja regional language is ma'ibadah which means 'thanksgiving worship'. For the people of the Tana Toraja region, the word tangkean suru indicates the support of relatives as a sense of love for the bereaved family which is manifested in the form of giving something at a funeral ceremony, such as giving buffalo and pigs. Furthermore, the word passar'kasan for the people of the Tana Toraja region, indicates the gratitude of the family due to the proper implementation of the funeral ceremony of a family member well.

\section{Quotation 21}

To makaka nauranni/Sa'bua' natarandakki/Ma' pare rante

puangta/Sali papa solanasang

[Nobles of the rain / Servant was soaked / our God indiscriminately

/ All the same before him]

In quotation 21 , there is a word ma'pare rante which in the daily communication of the peoplein the Tana
Toraja area is used the word napasama rata which means 'to do justice'. For the people of the Tana Toraja region, the word ma'pare rante signifies that God is just and indiscriminately towards all humans so that death will be experienced by all humans on this earth.

\section{Quotation 22}

Tonna sundunmo alukna / Tonna upu' bisaranna/Male titengka lentekna/Tibaen passoeanna [After completing the ceremony / Completed all the rites / Stepped foot / Departed him there]

In quotation 22 , there is a word tibaen passoeanna which in the regional language of Tana Toraja for daily communication is used the word malemo sau which means 'people who have left'. For the people of the Tana Toraja area, the word tibaen passoeanna signifies the person who has died.

\section{Quotation 23}

Malemo naturu'gaun/Naempa-empa salebu/Ullambi'mo pong lalondong/ Sola to bambana mukkun $[\mathrm{He}$ departed followed by clouds / Accompanied by mist / Getting heaven / Land of the dead]

In quotation 23, it is found the word pong lalondong which has the same meaning as the Tana Toraja regional language everyday puya or suruga, which is 'heaven'. The word bambana mukun in Tana Toraja regional language is lalan kamatean which means 'the way of death'. For the people of the Tana Toraja region, the word pong lalondong signifies the place of the deceased to be a saint. Furthermore, the word bambana mukkun for the people of the Tana Toraja region, marks a path to eternal life, namely death. 


\section{Quotation 24}

E...Puang e...Puang e...Puang e/

Puang matua dao tangngana langi'/

Puang dao ma'gulung-gulunganna/

Puang titanan tallu/Tirindu batu

lalikan [Ee ... God, e ... God, e ...

God e / God on the sky / God

on the clouds / God Tri Tungal /

Compassionate and Merciful]

In quotation 24 , there is a word tirindu batu lalikan in the daily language of the Tana Toraja region used the word pakamase sia pakaboro which is 'loving and compassionate'. For the people of the Tana Toraja region, the word tirindu batu lalikan indicates that God is the source of love and affection for all humanity.

\section{Quotation 25}

Anna bura'i lindo masakke/Anna pi'piki tanda marendeng/Anna rendenmi rekke tampona mata uai/Na balayanni rekke bakke' mata uai [So that you get safety / Get a long life / So deliver to the spring / Flow to the spring]

In quotation 25, there is a word lindo masakke which in daily language Tana Toraja uses kasalamaran which means 'safety'. Furthermore, the word tanda marendeng in Tana Toraja regional language is kalando umuru which means 'long life'. For the people of the Tana Toraja region, lindo masakke signifies salvation obtained from God because of the firmness of the faith they possess and the nature and conduct that is in accordance with God's command. Meanwhile, the word tanda marendeng for the people of the Tana Toraja region indicates the condition of someone who is old, but God has not called him.

Based on the data exposure in the above quote, it can be understood that vertically, the Tana Toraja community has a relationship with its creator, namely God. In establishing a relationship with God, they have concepts and outlook on life that function as a code of conduct that regulates, controls, and gives direction to their attitudes and actions in the life of God. The code of conduct is in the form of the values adopted by the community and selectively chosen by individuals or groups and is used as a guide in carrying out activities in their lives.

Tana Toraja's relationship with God is manifested in a form of their beliefs, especially related to the process of birth and death. These beliefs are the source and base of their attitudes in the life of God. Regarding this belief, in the Singgi' speech, it can be seen the attitude of the Tana Toraja community in their relationship with God, namely servitude to God through worship and prayer, recognition of God's nature, and belief in the way of life towards God. The cultural attitude recorded and reflected in the Singgi' speech is seen as a picture of the cultural attitude of the Toraja people in their daily lives.

The attitude of each human individual in relation to himself, his fellow humans, nature is a relationship that is both an appeal and paradox (Snijders, 2004). Relationships with each other lead to a unity, but each individual in the relationship unity leads to the uniqueness of who he really is (Hasanah et al., 2018). In relation to nature, humans become themselves by humanizing nature. Furthermore, as civilized creatures, humans claim to be creatures of belief. This religious dimension by Snijders is said to originate from each human being and 
be a material for reflection to deepen understanding of the human self itself. In reflection on the understanding of religious appreciation, humans find themselves directed to God.

The belief in the power and attributes of God fosters a positive attitude towards the individual Tana Toraja community for not acting unethically and behaving selfishly. This belief also fosters an attitude of surrender to God about all the effort he has done. Humans are only obliged to try, but the results of these efforts are decisive God. To achieve what is aspired, humans must endeavor and ask God that is manifested in worship behavior.

The belief in the attitude of godliness, in the daily life of the Tana Toraja people, looks at the harmonious relationships in social life. Although different beliefs or beliefs, they live in harmony. In everyday life, humans have an environmental ethic that cannot be released with the faith of religious people (Daldjoeni \& Suyitno, 1979). In this ethic, every human being must be responsible to God. To show this responsibility, the people of Tana Toraja always carry out their worship according to the rules in their respective beliefs. As God's creatures, humans are made in God's image. Therefore, humans must know that their God can be realized by always doing good, honest, respecting others, and not forgetting to always remember God by worshiping diligently.

\section{CONCLUSION}

Singgi' as the oral literature of Tana Toraja was built using the Toraja language. However, in the poem there are also some absorption words from Indonesian, both absorbed through adoption and adaptation. The absorption of the vocabulary reflects the limitations of the vocabulary in the Torajalanguage toaccommodatecertain concepts expressed in their speech. The absorption of the vocabulary is also a reflection that the culture of the Tana Toraja people experiences a dynamic in relation to their socio-cultural environment. In the Singgi' speech, also used many distinctive words of the Toraja language, namely the old vocabulary which is rarely used in daily communication. The use of the old vocabulary is intended to carry the right concepts related to the cultural attitudes of the Tana Toraja community. From these findings, it can be revealed that the vocabulary used in Singgi' speech reflects the cultural attitude of the people of Tana Toraja. This finding has important benefits in the cultural preservation of the Tana Toraja community, especially in maintaining the tradition of oral culture. In addition, this finding is also important for education, namely as teaching material for the development of character education. For further research, the results of this study can be used as a reference in the development of theory or as material for discussion of similar research results.

\section{ACKNOWLEDMENTS}

The writer wish to thank the Universitas Kristen Indonesia Toraja and Community leaders and tradition holders of Tana Toraja Community for supporting the study.

\section{REFERENCES}

Adam, K. M. (1990). Cultural Commoditization in Tana Toraja, 
Indonesia. Cultural Survival Quarterly Magazine. https://www. culturalsurvival.org/publications/ cultural-survival-quarterly/culturalcommoditization-tana-torajaindonesia

Adams, K. M. (1995). Making-up the Toraja? The Appropriation of Tourism, Anthropology, and Museums for Politics in Upland Sulawesi, Indonesia. Ethnology, 34(2), 143-153. JSTOR. https:// doi.org/10.2307/3774103

Conklin, J. E. (1984). Sociology, an Introduction. Macmillan.

Daeng, H. (2000). Manusia, kebudayaan, dan lingkungan: Tinjauan antropologis (Cet. 1). Pustaka Pelajar.

Daldjoeni, N., \& Suyitno, A. (1979). Pedesaan, lingkungan dan pembangunan. Alumni.

Danandjaja, J. (1984). Folklor Indonesia: Ilmu gosip, dongeng dan lain-lain. Grafiti Pers.

Fought, C. (2006). Languageandethnicity. Cambridge University Press.

Green, J. P., Dalal, R. S., Swigart, K. L., Bleiberg, M. A., Wallace, D. M., \& Hargrove, A. K. (2019). Personality Consistency and Situational Influences on Behavior. Journal of Management, 45(8), 3204-3234. https://doi. org/10.1177/0149206318781950

Hasanah, F., Subekti, M., \& Handayani, V. T. (2018). Makna Realisme Magis dalam Novel Jours de Colère dan 'Enfant Méduse Karya Sylvie Germain [The Meaning of Magical Realism in the Jours de Colère Novel and 'Enfant Méduse by Sylvie Germain]. Litera, 17(3), Article 3. https://doi.org/10.21831/ltr. v17i3.19990
Hd, D. S., \& Muttaqin, Z. (2018). Representasi Bangsawan Sasak dalam Teks Angin Alus Masyarakat Sasak [Representation of Sasak Nobles in the Angin Alus text of the Sasak Society]. Litera, 17(1), Article 1. https://doi.org/10.21831/1tr. v17i1.15291

Herianah, H. (2016). Representasi Nilai Budaya Himne Pasomba Tedong: Sebuah Cermin Kearifan Lokal Masyarakat Toraja (Representation of Cultural Values of Hymns Pasomba Tedong: A Reflection of Local Wisdom of Toraja Society). Balai Bahasa Jawa Barat.

Hutomo, S. S. (1991). Mutiara yang Terlupakan: Pengantar Studi Sastra Lisan [Forgotten Pearls: Introduction to Oral Literature Studies]. Himpunan Sarjana Kesusastraan Indonesia, Komisariat Jawa Timur.

Ibrahim, Saryono, D., \& Indraswari, R. (2006). Pergumulan Estetika Sastra Indonesia (Malang) [Struggling Aesthetics of Indonesian Literature (Malang)]. Malang: Pustaka Kayutangan.

Jones, T. (2015). Kebudayaan dan Kekuasaan di Indonesia: Kebijakan Budaya Selama Abad Ke 20 Hingga Era Reformasi [Culture and Power in Indonesia: Cultural Policies During the 20th Century Until the Reformation Era]. Yayasan Pustaka Obor Indonesia.

Koentjaraningrat. (2005). Pengantar Antropologi [Introduction to Anthropology]. Jakarta: Rineka Cipta.

Mooney, A. (Ed.). (2011). The language, society and power reader. Routledge.

Mulyana, D., \& Rakhmat, J. (2009). Komunikasi antarbudaya panduan 
berkomunikasi dengan orang-orang berbeda budaya. Bandung: PT Remaja Rosdakarya.

Nooy-Palm, C. H. M. (1975). Introduction to the Sa'dan Toraja people and their country. Archipel, 10(1), 53-91. https://doi. org/10.3406/arch.1975.1241

Pamungkas, S. (2012). Bahasa Indonesia dalam berbagai perspektif: Dilengkapi dengan Teori, Aplikasi, dan Analisis Penggunaan Bahasa Indonesia Saat ini [Indonesian in Various Perspectives: Equipped with Theory, Application, and Analysis of Indonesian Language Usage Nowadays]. Yogyakarta: C.V Andi Offset.

Pusposari, D. (2011). Mitos dalam kajian sastra lisan. Malang: Pustaka Kaiswaran dan Fakultas Sastra Universitas Negeri Malang.

Ricoeur, P. (2002). Filsafat Wacana: Membelah Makna dalam Anatomi Bahasa [Discourse philosophy: Splitting the Meanings in Language Anatomy]. Yogyakarta: IRCiSOD.

Sandarupa, S. (2015). Glokalisasi Spasio-Temporal dalam Agama Aluk To Dolo oleh Agama Kristen di Toraja [Spasio-Temporal Glocalization in Aluk To Dolo Religion by Christianity in Toraja]. Sosiohumaniora, 17(1), 86-93. https://doi.org/10.24198/ sosiohumaniora.v17i1.5677

Shen, B., Qu, W., Ge, Y., Sun, X., \& Zhang, K. (2018). The Relationship between Personalities and Selfreport Positive Driving Behavior in a Chinese Sample. Plos One, 13(1), e0190746. https://doi. org/10.1371/journal.pone.0190746 Sikki, M. (1986). Struktur Sastra Lisan Toraja: Transkripsi dan
Terjemahan [Toraja Oral Literary Structure: Transcription and Translation]. Pusat Pembinaan dan Pengembangan Bahasa, Departemen Pendidikan dan Kebudayaan.

Snijders, A. (2004). Antropologi Filsafat Manusia: Paradoks dan Seruan [Anthropology of Human Philosophy: Paradoxes and Exclamations]. Yogyakarta: Kanisius.

Sudarsi, E. T., Taula'Bi', N., \& Allo, M. D. G. (2019). Filosofi Tallu Lolona dalam Himne Passomba Tedong (Etnografi Kearifan Lokal Toraja) [The Philosophy of Tallu Lolona in the Hymns of Passomba Tedong (Ethnography of Torajan Local Wisdom)]. Sawerigading, 25(2), 61-73. https://doi.org/10.26499/ sawer.v25i2.666

Sugiarti, S., \& Putra, C. R. W. (2019). Representation of Culture Ecology in Wisran Hadi's Persiden, Generasi Ketujuh. Litera, 18(1), 17-35. https://doi.org/10.21831/ 1tr.v18i1.20579

Sumaatmadja, N. (2003). Manusia dalam Konteks Sosial, Budaya dan Lingkungan Hidup [Humans in Social, Cultural and Environmental Contexts]. Bandung: CV Alfabeta; Alfabeta. http://lib.ui.ac.id

Sumaryono, E. (1999). Hermeneutik, SebuahMetodeFilsafat [Hermeneutics, a method of philosophy]. Yogyakarta: Kanisius.

Suryani, W. (2013). Komunikasi Antar Budaya yang Efektif [Effective Intercultural Communication]. Jurnal Dakwah Tabligh, 14(1), 91100. https://doi.org/10.24252/jdt. v14i1.316 
Tanduk, R.(2012). Analisis Penggunaan Majas dalam Singgi [Analysis of Use of Majas in Singgi]. AgroSainT, 3(2), 302-302.

Tanduk, R., Darwis, M., Maknun, T., Usman, M. (2016). Symbolization of Meaning of Singgi'Tedongin Traditional Ceremony "Merauk Tongkonan RambuTuka' "at Tana Toraja. International Journal of Science and Research (IJSR) Volume 5 Issue 12, December 2016. http:// https://www.ijsr.net/archive/ v5i12/ART20163851.pdf

Thomas, L., Wareing, S., Jones, J., \& Thornborrow, J. (2004). Language, Society and Power: An Introduction. New York: Psychology Press.

Udiati, T. (2016). Sikap Pembauran Sosial dan Prasangka Etnisdalam Masyarakat Multikultural (Yogyakarta) [Social Assimilation Attitudes and Ethnic Prejudices in Multicultural Communities (Yogyakarta)]. B2P3KS-Yogyakarta. //digilib. unri.ac.id/index.php?p=show detail\&id $=84806 \&$ keywords $=$
Wardhaugh, R. (2009). An Introduction to Sociolinguistics. Oxford: John Wiley \& Sons.

Wehmeyer, M.L., \& Palmer, S. B. (2003). Adult Outcomes for Students with Cognitive Disabilities Three-Years After High School: The Impact of Self-Determination. Education and Training in Developmental Disabilities, 38(2), 131-144.

Wortham, S., \& Perrino, S. (2017). Linguistic Anthropology of Education. In S. Wortham, D. Kim, \& S. May (Eds.), Discourse and Education (pp. 3-13). Springer International Publishing. https:// doi.org/10.1007/978-3-319-022437_5 